\title{
Serological Testing for Herpes Can Lead to Misinterpretation in Disease Transmission
}

\author{
Craig G. Burkhart ${ }^{*}, 1$ and Craig N. Burkhart ${ }^{2}$ \\ ${ }^{1}$ University of Toledo College of Medicine, USA \\ ${ }^{2}$ University of North Carolina at Chapel Hill, Chapel Hill, North Carolina, USA
}

\begin{abstract}
Herpes is a ubiquitous virus which can produce orolabial and genital infections in humans. Multiple laboratory tests are available to diagnose herpes infections including viral culture, direct fluorescent antibody assays, molecular techniques, and serology. The use of serological markers has lead to numerous epidemiological studies, but there results can be misleading. Seropositivity merely signifies that a person reacts in a specific type of immunological response to specific viral proteins, it certainly does not rule out the existence of the virus in the host. Serological testing for fungal or most viral infections do not approach total diagnostic accuracy. The numerous herpes transmission studies based exclusively on serological testing and seroconversion (despite being published in esteemed journals) have major deficits and may well not be clinically significant.
\end{abstract}

Many studies concerning herpes simplex (HSV) infections based on serological factors have greatly overstated their significance and can lead to erroneous assumptions. Examples include:

- $\quad$ HSV-2 seropositivity has been found to be $86 \%$ in some locations [1].

- $\quad 22 \%$ of Americans are serologically positive for HSV-2, which is touted to be almost exclusively transmitted sexually, but HSV-2 seroprevalence is over $28 \%$ in monogamous couples in certain locals [2].

- $\quad$ Despite seropositive people shedding the virus almost one-third of the time by PCR testing [3], numerous heterosexual couples with discordant HSV serologic pictures exist $[4,5]$. To be sure, mates of seropositive people are constantly exposed to the virus, yet do not convert by blood testing because they react immunologically differently to viral exposure.

With herpes, polymerase chain reactions and cultures provide the best opportunity to make a definitive diagnosis, but such testing may require invasive procedures to maximize yield and may not be applicable in many settings. Serology is merely one alternative means of diagnosing and occasionally monitoring disease.

Serology has the obvious limitation that one cannot distinguish active infection from remote exposure or resolved infection. These tests are not capable of detecting early infection and may require serial testing for improved sensitivity.

More importantly to this discussion, seropositivity merely signifies that a person reacts in a specific type of

*Address correspondence to this author at the University of Toledo School of Medicine, 5600 Monroe Street, Suite 106B, Sylvania, OH 43560, USA; Tel: 419-885-3403; Fax: 419-885-3401; E-mail: cgbakb@aol.com immunological response to specific viral proteins. Some patients may react immunologically differently to the presence of the same viral proteins. Present serological testing does not rule out the existence of the virus in the host. An example with herpes zoster, only $61 \%$ of infected individuals are seropositive [6]. Rarely do serological test for fungal or viral infections approach total diagnostic accuracy. Moreover, HSV-1 infections are probably universal, and HSV-2 exposure is probably much more common than appreciated. For example, semen specimens in one American study revealed that $50 \%$ of male patients had culture-proven HSV-2 in an infertility clinic [7]. For the most part, there is poor appreciation that HSV is found within the epidermis as well as within the parenchyma and stratified squamous epithelium of virtually all organs of the body [8].

Surprisingly, herpes is not a bad virus (despite what you read in the media). The virus appears to share a symbiotic relationship with humans [8]. It is part of the evolutionary innovations of cooperative symbiosis among organisms. Although the herpes virus can act as a pathogen causing serious disease, the virus also offers benefit to its host as well. Herpes virus offers its human host oncolytic, immunestimulating, and anti-tumor properties [8]. The virus thrives in many types of cancer cells and shows selective damage as well as initiating an immunological response to cancerous cells. Genetically- engineered herpes virus has shown promise in the treatment of several cancers. The virus's frequent presence at sites of potential or existent irritation or disease may reflect this beneficial, protective trait for the host. On closer inspection, maybe herpes is a good thing, at least in part.

Serology alone cannot tell if prevalence rates are changing or even if one is infected with the virus or not. In short, our view is that serological testing may not report HSV status correctly. The PCR-based HSV testing is more trustworthy and this latter technique should be strongly considered for clinical and epidemiological studies. The numerous herpes transmission studies based exclusively on serological 
testing and seroconversion (despite being published in esteemed journals) have major deficits and may well not be clinically significant.

\section{REFERENCES}

[1] Uribe-Salas F, Conde-Glez CJ, Juarez-Figueroa L, HernenadezCastelloanos A. Socio-demographic characteristics and sex practices related to herpes simplex virus type 2 infection in Mexican and Central American female sex workers. Epidemiol Inf 2003; 131: 859-65.

[2] Rodriguez AC, Castle PE, Smith JS. A population based study of herpes simplex virus 2 seroprevalence in rural Costa Rica. Sex Transm Infect 2003; 79: 460-5.

[3] Wald A, Corey L, Cone R, Hobson A, Davis G, Zeh J. Frequent genital herpes simplex virus 2 shedding in immunocompetent women. Effect of acyclovir treatment. J Clin Invest 1997; 99: 10927.

[4] Mertz GJ, Benedetti J, Ashley R, Selke SA, Corey L. Risk factors for the sexual transmission of genital herpes. Ann Intern Med 1002; 116: 197-202.

[5] Corey L, Wald A, Patel R. Once-daily valacyclovir to reduce the risk of transmission of genital herpes. NEJM 2004; 350: 11-20.

[6] Wald A, Zeh J, Selke SA, Ashley RL, Corey L. Virologic characteristics of subclinical and symptomatic genital herpes infections. $\mathrm{N}$ Engl J Med 1995; 333: 770-5.

[7] Kapranos N, Petrakou E, Anastasiadou C, Kotronias D. Detection of herpes simplex virus, cytomegalovirus, and Epstein-Barr virus in the semen of men attending an infertility clinic. Fertil Steril 2003; 79: 1566-70.

[8] Burkhart CG. Herpes acquisition and transmission. J Drugs Dermatol 2005 ; 4 : 378-81.

(C) Burkhart and Burkhart; Licensee Bentham Open.

This is an open access article licensed under the terms of the Creative Commons Attribution Non-Commercial License (http://creativecommons.org/licenses/by$\mathrm{nc} / 3.0 /$ ) which permits unrestricted, non-commercial use, distribution and reproduction in any medium, provided the work is properly cited. 